
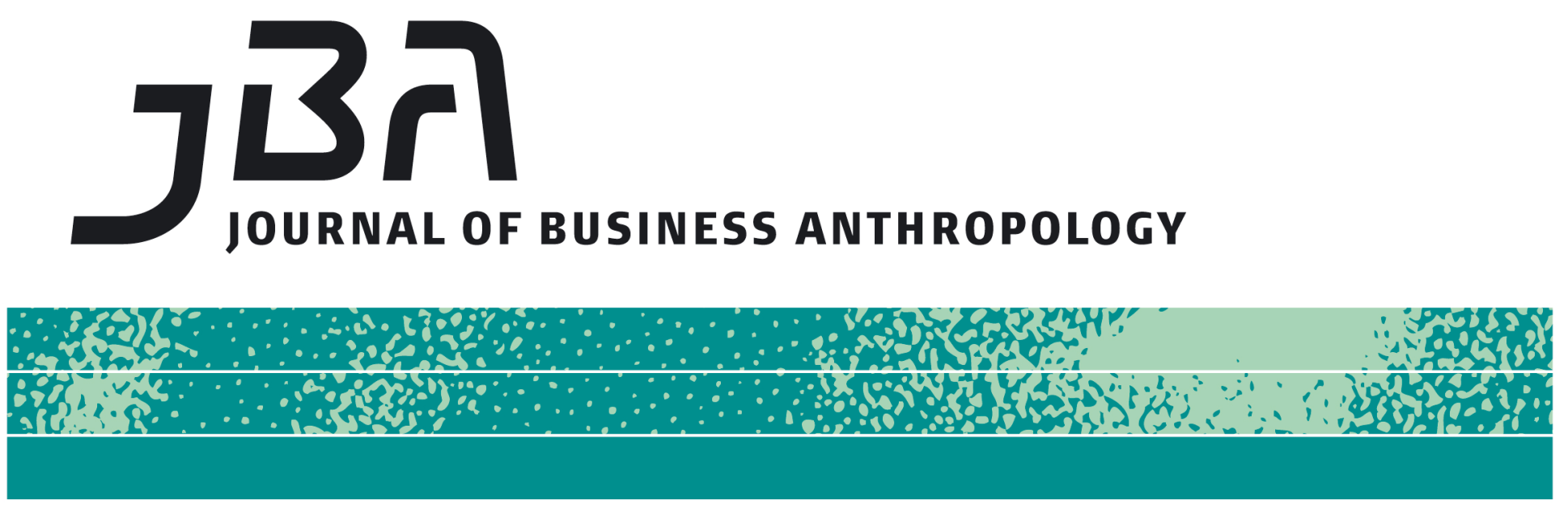

\title{
Design Anthropology as Social Design Process
}

\author{
Siobhan Gregory
}

\begin{abstract}
As professionally trained designers position their practices as central to social change, they bring with them efficiency in process, technical expertise, sophisticated aesthetic skills, and highly scripted narratives. In economically challenged cities like Detroit, creative professionals are hired to help transform neighborhoods that are described as abandoned, disorderly, and "blighted". Residents of these neighborhoods are increasingly asked to engage in stakeholder meetings and design charrettes that promise greater inclusion and "a voice" in the process. These activities and interventions are sometimes framed as Design Thinking, human-centered design, or participatory design. However, as designer-adapted, re-contextualized anthropological methods, these approaches may ultimately diminish the value and understanding of applied anthropological enquiry. The author argues that design anthropology can offer a deeper, more grounded, and more equitable approach to design and design research processes in contexts of "urban renewal."
\end{abstract}

\section{Keywords}

Social design, urban renewal, gentrification, ethnography, design anthropology
JBA 7(2): 210-234

Autumn 2018

(C) The Author(s) 2018

ISSN 2245-4217

www.cbs.dk/jba 


\section{Introduction}

In social design practice, designers must sometimes adapt to settings where no object or physical space is being designed and where they must negotiate different agendas, resources and power relations among a diversity of stakeholders (Bannon and Ehn 2012). Where social design meets ethnography, there is often a meshing of roles where researcher becomes design facilitator and designer becomes research investigator (Kjærsgaard and Boer 2015). Designers and design researchers that are oriented towards sponsor or organizational outcomes and more comfortable with the timeframes of the private sector may move quickly to assert actionable insights and implement what they perceive as solutions. Human-centered design, design thinking, and inclusive or participatory design offer an alternative approach for social design processes. Hunt explains that these approaches "signal that designers are increasingly adopting the tools of social observation as resources for local knowledge to better inform and inspire the development of new ideas" (Hunt 2011:33-34). Bichard and Gheerawo explain that inclusive design is also "recognized by governments as a force of social equality as well as a driver of social innovation for communities, business and industry" (Bichard and Gheerawo 2011:45). However, while these designeradapted, ethnographic-inspired methods may offer pathways to creative insight, they are not intended to do more than that: they are not intended to deliver a deep comprehensive understanding of the day-to-day lives of the people who live in these communities. Bichard and Gheerawo question whether the "hard-and-fast rules of ethnographic data analysis" and rituals of anthropological practice that entail weeks, months, and often years of time in the field and painstaking analysis of interview and field data would even be useful to designers (Bichard and Gheerawo 2011:46). It has also been argued that by engaging in designer-adapted ethnographic approaches, social designers today are likely to miss the depth of analysis of more traditional forms of anthropological inquiry (Wasson 2000; Cefkin 2012; Miller 2014).

I argue that design anthropology offers an alternative approach to design thinking, human centered design and inclusive design that is better suited to social design process. Central to this argument is the idea that design anthropology is a social design process that prioritizes socially transformative goals over "empathy-building" activities and design "interventions." Design anthropology may also produce greater social outcomes through longer-term, embedded approaches which are more aligned with the work of grassroots social organizations. This article builds the case that design anthropology may offer a viewpoint for designers to more effectively approach the work of social design. First, this article introduces some of the limitations of social design and social design process today, discussing forms of displacement in the design and planning processes as factors of inequality. It references Detroit to help 
illustrate existing issues of inclusion and equity in design and urban planning. Second, this article discusses three key distinctions of design anthropology that could better inform a social design process: reflexivity of the designer, new ways of knowing, and embeddedness.

\section{The Limitations of Designer-Adapted Ethnography for Social Design}

Design as a source of social good is not a new position for the design and architectural communities, but has grown to prominence in the last decade. Beginning In the 1960s and 70s designers like Buckminster Fuller (1967) and Victor Papanek $(1971,1984)$ helped to steer the practice of design in directions beyond pure consumerism and towards more global humanitarian and environmental outcomes. The role of the "humanitarian designer" offered "a new power for the designer to participate in projects for the welfare of humankind, both inside and outside the market economy" (Margolin 1998:87-90). This period also saw the coming together of design and anthropology, which offered an "alternative model of non-capitalist creativity." (Clarke 2011:74) Design is now widely recognized as a vehicle to solve a wide range of complex social issues (Otto and Smith 2013; Pink 2014; Hillgren et al. 2011) but has limitations when applied to social innovation. Professional designers typically understand design process to be project-based and prioritize immediate or close-future solutions rather than long-term implications (Light 2015). Well paid designers often "parachute" into poor areas with overblown claims of design's value and a "tendency to reinvent the wheel" with little regard for past work done and past lessons learned (Mulgan 2014:5). The consultant-based models of the design profession, typically structured by closed-ended assignments, project-based relationships, lean and agile methods, and quick turnarounds are not aligned with social organizations that take a slower approach and collectively work towards a long-view of social change. ${ }^{1}$ The following sub-sections further explore issues with the consultant-based model as applied to social design process.

\section{Authorship, Ownership and Positioning}

Questions of authorship and ownership are central when it comes to designers' motivations to "change the world" (Miller 2014; Nussbaum 2010). Designers typically emerge from elite design schools and other higher education institutions (Otto and Smith 2013) with rigorous

\footnotetext{
${ }^{1}$ I credit designer and design researcher Linda Pulik here. Our analysis of the consulting-based model of social design, along with the other points of criticism were first presented by Linda and me at the Design Research Conference in Chicago on October 9, 2013. Our talk was entitled "Deep Design; Reclaiming Patience in Design for the Social Sector." It was the inspiration for this article.
} 
curriculums, short-term deliverables, and competitive environments. They are considered to hold special knowledge, training, skills and talents. Therefore, in social design engagements, an imbalance of power can naturally exist even when participation and consensus is encouraged (Bush 2003; Sacchetti 2011). Furthermore, the needs of poor communities are often framed with a moral tone as opportunities for designers to solve "wicked problems" (Buchanan 1992). By transgressing space and socioeconomic status, the designer can build a self-image of bravery and edginess, altruism and sacrifice. The technical knowledge of the designer enables them to manage concept visualization and the design production process. As an outsider, the designer is often placed at the center of impact and the resident participants at the fringes as recipients or beneficiaries. For social impact initiatives, this positioning can have negative consequences when there is an expectation of shared authorship or community embedded-ness.

The positioning of designers and "creatives" in Detroit's urban renewal narrative of the past eight years is an example of this dynamic. Positioned by the media as a blighted, empty wasteland and 'blank canvas' waiting to be reimagined by developers, entrepreneurs, cultural workers, and members of the creative class, the narrative of Detroit's "comeback" privileges "pop-ups," "start-ups," "bootstrappers" and "urban pioneers" (Gregory 2012 and 2015; Bergland 2017; Montgomery 2015). Some backlash toward newly arriving creative talent is driven by concerns of increasing gentrification and lack of representation of the demographic diversity of local entrepreneurs and existing residents' contributions to neighborhood stability, crime prevention and blight mitigation. In 2013, an image of the young entrepreneur Jason Lorimer, co-founder of the company Dandelion, went viral in the local media when his image was turned into dozens of versions of "the white entrepreneurial guy" meme. Dandelion refers to itself as a technology company focused on serving nonprofit organizations and their portfolio includes marketing, web and mobile app design, print design, video, financial advising, and more. (Dandelion) In the opinion piece entitled "Detroit is the Opportunity of a Generation," which was associated with the memes, Lorimer states, "I am not from Detroit, yet, in the 14 months since I have lived and loved in this place, my team and I have managed to gain access to and partnered with a myriad of civic-minded institutions to provide new ideas and measurable outcomes in the communities they wish to affect" (Lorimer 2013). Lorimer's story struck a chord with the public because it got to the heart of concerns about outside talent having greater access, influence and mobility (Foley 2013, Woods 2013). The "white entrepreneurial guy" memes indicated a shared understanding that outside experts often receive privileged access to resources.

In Detroit and in many other low income urban communities, grassroots social organizations are typically slower growing, slower to 
procure funding, and more fluid in their organizational structure. They may start with small groups of like-minded allies and grow to involve complex networks of support and funding and/or more organized campaigns (Mulgan et al. 2007). They may have significant financial and political barriers to work through, both intellectually and logistically. For social designers and social design initiatives, the "white entrepreneurial guy" memes indicates that attempts to promise outcomes in a week or a month would be met with distrust and possibly distain. This next subsection discusses similar questions of authorship and ownership in social design process, and how "inclusion" as a design process activity can get in the way of shared authorship and ownership.

\section{"Deep Dives," "Empathize Mode" and Quantified "Inclusivity"}

The Human Centered Design Toolkit produced by the design firm IDEO offers "scenarios of use" framed as "the week long deep dive" and the "several month deep dive" (IDEO 2011:14-17). These short timeframes and fast-paced ways of working evidence a strong connection to business consulting, where one week may be enough time to draw fast conclusions and rapidly prototype design ideas to test. This introduction indicates that the purpose of the kit is to help the user enter new markets, identify growth opportunities and "bring innovation to the base of the pyramid" (IDEO 2011:1). In this example, human centered design is presented as flexible, rapid, efficient, and focused on market expansion. Another well known designer-adapted ethnography toolkit is the Hasso Plattner Institute of Design at Stanford document called the "d.school Bootcamp Bootleg." The "Bootcamp Bootleg" presents "empathizing" as a "mode" in the design thinking process, along with defining, ideating, prototyping, and testing (The Hasso Plattner Institute of Design at Stanford). The document does not refer to participant observation or ethnography. However, it includes the terms "empathize mode" and "empathy work," along with methods referred to as "analogous empathy" and "interviewing for empathy." Here empathy is presented as a combination of distinctly labeled tasks in the design process.

As design tools, both of these examples prioritize "insights" and the potential for material outcomes, but not sustaining partnerships or alliance building. "Deep dives" and "empathy work" methods may be well suited for the private sector, but in social design process that engages public partners, quick immersions may also limit human intuition in the collaborative creative process - the corporeal feeling of trust and partnership. As Tunstall (2013) argues, the IDEO and the Rockefeller foundation design for social impact initiative has imperialist implications in the framing of who generates innovation. She explains that in the two documents produced by the initiative, Western design companies are often the recipients of the materials and resources. This positions them in 
a unique hierarchical position to lead non-Western institutions in solving problems, and in turn transfer resources of foundations and NGOs to Western design firms. Furthermore, Tunstall critiques the design thinking framework as potentially ignoring indigenous forms of knowing and models of problem solving. She calls for the need to "decolonize" processes of design and anthropological engagement, towards greater self-governance and independence.

Detroit Future City Plan (DFC) is an example of the need for "decolonization" in social design process. Detroit has a history of distrust in the planning process, with significant hurdles to participation attributed to a strong sense of neighborhood autonomy and a legacy of neighborhood-based coalition building that kept communities in tact during years of economic divestment (Brookmeyer 2000). When the DFC was formulated, significant efforts were made towards community "stakeholder" inclusion in the planning process, yet these efforts were unsuccessful in meeting the level of inclusivity desired by many residents (Montgomery 2015). The DFC is a 50-year strategic framework plan for the city funded by a public-private partnership between the Kresge, Kellogg, and Ford Foundations (Detroit Works Project Long Term Planning Committee 2012, Clement and Kanai 2015). Disseminated in January 2013, the DFC plan includes a strategy of expansive "green and blue" infrastructure, promoting sustainability and greening, improvement of parks and the riverfront, urban farms and storm-water retention, along with a re-vitalized/re-densified downtown.

Montgomery (2015) refers to the "sustainability fix" to explain how the DFC strategy used the promise of green and blue infrastructure to mobilize cultural workers (defined as artists, clergy, and intellectuals) towards a development agenda of "growth elites" (defined as leaders in business, finance, philanthropy, and real estate). As efforts towards inclusion, the Detroit Works Project team used " 26 engagement tactics" (Lewan 2014) including hosting many community meetings and town halls, along with a storefront office and traveling display called a "roaming table" (Montgomery 2015, Lewan 2014). In a recent interview, Dan Pitera, the lead planner of Detroit Future City Plan, shared that efforts towards inclusion in this process were understood to be successful. Pitera is an architect and self-proclaimed social activist. He is the Executive Director of the Detroit Collaborative Design Center at University of Detroit Mercy, which "is dedicated to fostering university and community partnerships that create inspired and sustainable neighborhoods and spaces for all people" (Detroit Collaborative Design Center). In the interview, Pitera states that, "in the process that led to the Detroit Future City Plan, we engaged 90,000 Detroiters in a city of roughly 700,000 people. That level of inclusivity is really unprecedented anywhere" (Blouin 2017). In this example, success is framed through a quantitative perspective and "inclusivity" as a "level" to be measured. 
Furthermore, Montgomery (2015) concludes that the engagement strategy presented what she refers to as "open closure" whereby the planning process was positioned as endlessly open, while elites made decisions behind closed doors.

In February of 2014, a local activist granted me permission to cite one of her Facebook posts from February 26, 2014, responding to a public forum about the DFC plan. Her quote is reflective of Montgomery's analysis. Here is a segment of that post:

Shameful for Dan Pitera. These folks are pimping a grassroots movement for money, power, fame - Shame on them! Dan Pitera lives in suburban bliss but he has credentials in speaking on our communities plight and 'what we need to do'? It figures!... Black women sitting in the room and emailing everyone \& speaking truth to power regarding these plans were marginalized, dogged out and had backs turned on them. Now some elite (several) shows up with the same information (packaged differently) and everyone is present, bright-eyed, bushy tailed! What is this, if not racist, and internalized hierarchy/superiority/inferiority complex in full display!

The activist's passionate post rallied for better representation in planning processes. Her thoughts are illustrative of the challenge when efforts towards inclusivity are understood differently by the technical experts framing the efforts and the intended recipients of their efforts. From a design anthropology perspective, the effort towards inclusivity and the perceived lack of inclusivity indicates that the approach was more design-centric than social-centric, through project-centric structuring and "top-down perspective that hinder[s] adaptation to changing conditions" (Bjögvinsson, et al 2012:103). The quantitative measuring of inclusion (i.e. 90,000 Detroiters) also shows a prioritization of scale over depth, which supports a robust activity of listening and learning that speaks the language of inclusion, but not true ownership.

As an illustrative example, Montgomery's (2015) analysis of the Detroit Works Project planning efforts towards the DFC plan shows how participants can feel displaced by design research approaches that feel imposed and overly formalized rather than conversational. This example also supports Miller's (2014) distinction between anthropology and design. She writes that, "in contrast to anthropology's unwavering focus on situated human social and cultural contexts, for design the 'plan' itself is the central focus of attention" (Miller 2014:65). In the example of the DFC community engagement efforts, the successful execution of a planned process may have been prioritized over actual success at "inclusion."

While the planning process can illustrate visions of urban renewal, the presence of designers and other "creatives" in urban spaces can communicate more immediate warnings that an area is gentrifying 
and that displacement is imminent. The "creative class" once considered beneficial to economically depressed neighborhoods that promise cheap real estate (Florida 2002) can do long-term harm to existing communities by driving economic disparities and displacement (Florida 2013). Indication that design (and designers) are arriving can work against social design process. This next section discusses the more complex factors involving the presence of designers and other creatives in low income areas and the significance for social design process.

\section{Designer-ly Interventions}

In the book All That is Solid Melts into Air: The Experience of Modernity (1982) Marshall Berman explores how divisions of class are materialized through the modern city and modern ideals of 'the developer' in bringing about class divisions. With illustrative reference to Faust, Berman discusses how modern values of development, expansion, flow, and newness plunged cities like Paris and New York into conditions of social crisis through the destruction and homogenizing of space and the removal of the "people in the way". Divisions created by massive infrastructural development projects of modernity are inherently connected to displacement and the economic disenfranchisement of poor residents and local independent businesses that results when neighborhoods are decimated (Jacobs 1961; Ross 1988; Lefebvre 1967 translated 1996; Harvey 2012). Design can reinforce class separation, policing, privatization, and the persistence of racial inequality through the built environment (Fry 1989; Schein 1999; Wilkins 2007; Maldonado and Cullars 1991; Cresswell 2006). It is therefore complicit in this process. Design ideologies of 'new urbanism' and 'placemaking' shift the focus of governance from the public sector to the private sector while retail, entertainment, and luxury residential schemes up-sell urban life as a form of tourism (Swyngedouw et al. 2002; Harvey 2012; Rutheiser 1997). High-end urban developments create "islands of wealth" (Swyngedouw et al. 2002) that reveal a fear of unknown outsiders and appeal to suburban values of privacy and retreat from society (Low 1997, 2009, Maldonado 1991). Sleek signage, trendy storefronts, expensive restaurants, craft breweries, an increase in outdoor cafe tables, are easily recognized tropes of gentrification. By design, and as a means to attract more design, the professional creative community is central to gentrification, as cultural influencers, as hired hands, and as higher-income residents who can afford these amenities.

Development projects in Detroit remove "people in the way," with luxury architectural renovations and new buildings, "placemaking" initiatives, an influx of high-end retail flagship stores. The media positions Detroit as an emerging "hotbed" of luxury and trendiness in its promotion of youth, risk, and transience as key to the city's "comeback" (Ager 2017, 
Applebome 2016, Scipioni 2015, Fournier 2015). One example of increased gentrification is renovation of The Albert in the Capitol Park area of Downtown Detroit. The website describes The Albert as a place of "modern comfort, historic charm and unique amenities" and the tagline reads "That's right, I live in Detroit" (The Albert Capitol Park). During the renovation process of the building - formerly called The Griswold - all of the building's former tenants were evicted. These were mostly senior citizens and People with Disabilities who were receiving Section 8 subsidies (McGraw 2013). As pioneers of new and unexpected territories for their social class, the tagline "That's right, I live in Detroit" encourages residents that by living at The Albert they are engaging in something remarkable, yet with the security and convenience of a luxury apartment building. Furthermore, according to the website for the Downtown Detroit Partnership, "Capitol Park is envisioned to be the center of an emerging arts district and residential neighborhood with galleries and cafes on the ground floors and residential apartments above" (Downtown Detroit Partnership). Development projects like The Albert and Capitol Park become an issue of context in gentrifying cities whereby social designers must then work against a perception of design as exclusive and elite.

Using examples from Detroit, this section presented barriers to inclusion, authorship, and contextual factors of gentrification that illustrate the challenges that may influence social design process. From a design anthropology perspective, participatory research methods could better allow for collaboration between 'researcher' and 'researched' and build both cultural awareness and a shared process (Murray et al. 2010). Longer periods of engagement, along with more experimentation and evaluation of methods and approaches could bring value to understanding and responding to the broader context of people's lives (Mulgan 2014). This next section explores these ideas further.

\section{Participatory Design and Design Anthropology as Social Design Process}

Graffam (2010) describes participatory design as the inclusion of end users (or participants) in the design process to allow for participant observation, while also providing opinions and feedback on a product's usability and whether a design will effectively meet the needs of its intended end users. Light (2015) describes participatory design practices more broadly as a form of 'constitutive anthropology' that is more democratically oriented to create new ways of being and new social arrangements. As a dimension of design anthropology, participatory design is unique from design thinking and user centered design because it entails an ongoing investigation on how to involve users as fully active partners in design, including how and by whom participation is 
negotiated and defined (Robertson and Simonsen 2012). Participatory design can provide guiding principles of mutual respect and sharing of knowledge and the mutual negotiation and development of participatory processes whereby participants help define goals and have a voice in project outcomes (Blomberg and Karasti 2015). Bjögvinsson, et al. (2010) describe participatory design as "infrastructuring" which demands extensive collaboration over time and among many stakeholders. Infrastructuring can foster democratic values in process while envisioning use before actual use. Infrastructuring aligns socio-material factors when design development is happening, at times when designs are being interpreted and articulated, and later when designs are adapted and appropriated by users (Bjögvinsson, et al. 2012). Infrastructuring also considers the tacit knowledge of participants and how that knowledge can come into play in the design process. In these ways, infrastructuring can help move the understanding of design from projectbased models to more open-ended long-term, and collaborative processbased approaches (Bjögvinsson, et al. 2010). A slower pace of working and the inclusion of many stakeholders is both critically important and methodologically necessary. The participatory design movement brings new challenges regarding how design is defined in the social innovation space: as a product, service, or, as Björgvinsson et al. (2010) write, a principle, an idea, a piece of legislation, a social movement, an intervention, or some combination of these. Participatory design is intended to be flexible and ready for anything (Light 2015).

Other theoretical aspects of design anthropology can go deeper than participatory design. While design and anthropology are often seen as separate and distinct parts of a process, design anthropology offers an approach to understanding the cultural impact of design while creating design. In this way, design anthropology is cyclical, critical and collaborative and unlike the more start-to-finish objectives of design projects. Thus, a design anthropology project can be open ended and ongoing (Gerber 2015). Design anthropology can also suggest a slower, more conscientious way of working that puts people and culture at the center of the design process. The following sub-sections reference scholarship in design anthropology and social design to articulate three dimensions of design anthropology that could be critically valuable to social design process: a 'reflexive' repositioning of the designer, design anthropology as 'new ways of knowing', and the value of an embedded, long-term approach.

\section{Social Design Process and "Reflexivity"}

Bannon and Ehn (2012) assert that the historic focus on "the cult of the designer" leaves little room for inclusion of others in their design visions. In critical design practices, the designer is placed in a morally or 
intellectually superior position of all-knowing authorship (Bowen 2010). The identity of designers is deeply connected to the training they receive and to the things that they make. When the designer's designs are made — fabricated in the material world - the designer legitimizes their training and professional identity. With this in mind, Fry (2008:11) argues that design theory continues to have "a narrow, reductive focus of design being done by designers" and that, with an ontological shift, a "remade professional" is needed in order to bring about any real change.

According to Bjögvinsson, Ehn, and Hellgren (2012:101), in participatory design for social innovation, "the design community is challenged to think beyond both the omnipotent designer and the obsession with products, objects, and things" to see design as a more collaborative effort with a diversity of stakeholders and competences. To this end, design is also recognized as a natural human instinct and not merely a professional distinction (Norton 2012; Manzini 2015; Cross 2011). Gatt and Ingold (2013:139) write that design "distinguishes even the most inept of human makers from the most accomplished of animals." Cross (2011:4) writes that "design ability used to be somehow a collective or shared ability, and it is only in fairly recent times that the ability to design has been regarded as a kind of exceptional talent." Furthermore, Manzini (2015) discusses how the terms 'design' and 'designer' are now used to describe a way of thinking and behaving well beyond what has been traditionally acknowledged, resulting in a range of meanings and misunderstandings.

As social organizations grow and become more flexible, members cultivate their design capacity. They are adopting what Manzini refers to as a "diffuse design" mode, or design by non-experts using a natural designing ability (Manzini 2015). Ultimately this shift will require better frameworks for collaboration (Manzini 2015; Akama, Stuedahl, and van Zyl 2015) in order for design to "disrupt its own power." (Akama, Stuedahl van Zyl 2015:142) "Where the 'design' enterprise can be extraneous, paradoxical and linearly inclined," design anthropology and participatory design "must problematise within its discipline and methodological approaches toward complexities of social processes of change," to engage with cultural resistance and conflict, and to embrace failure (Akama, Stuedahl van Zyl 2015:144). Akama, Stuedahl and van Zyl (2015) further consider "design disruptions" as inherent stress that comes with changes caused by design interventions when values, emotions, mindsets and expectations are not aligned.

In order to move forward in a more socially minded way, designers will need to recognize these issues, and, ultimately, a more reflexive approach to the 'designer' title will be necessary to create a more socially inclusive process. In contexts of urban renewal, designers can develop greater awareness of what the field has traditionally prioritized and the aesthetic implications of how design affects people's 
sense of place and access. Designers could bring to their work a greater sensitivity to how visual communication, through professional design aesthetics, can signal gentrification through architectural materials, color, signage, and printed elements, and the ways that these factors exclude residents and other stakeholders while encouraging outside investment and patronage. It is expected that the "planned shrinkage" of the Detroit Future City Plan will disproportionately affect the city's poorest and most isolated residents and is therefore a form of "racialized spatial injustice" (Clement and Kanai 2015; Kirkpatrick 2015). It would bode well for designers to engage in these discourses and recognize the complicit role of design as a driver of displacement. While greater "reflexivity" may help to shift the title and meaning of designer, design anthropology can also help designers to articulate the significance of shared "ways of knowing" and shared "futuring" in social design process. This next sub-section explores this idea further.

\section{Social Design Process and 'New Ways of Knowing'}

Where participatory design meets design anthropology, design's orientations towards material interventions and future-making (Otto and Smith 2013; Akama, Stuedahl and van Zyl 2015; Akama, Pink, and Fergusson 2015; Kjærsgaard and Boer 2015) meet anthropology's inherent interest in the past (Gatt and Ingold 2013), the evolution of culture and the human experience. Beyond ethnography, design anthropology offers a future-orientated methodology. Design anthropology engages with design activities as a form of inquiry into "emerging worlds and possible, potential alternatives" (Akama, Stuedahl and van Zyl 2015:132). This bringing together offers an "ethnography of the possible" through a temporal trajectory of past, present, and future (Stuedahl 2015). Design anthropology removes a clear-cut correlation between a future orientation and a past orientation, and instead offers an intertwining of multiple spatio-temporal orientations and alternative perceptions of time framed by multiple histories and "diverse manifestations of the possible" (Anusas and Harkness 2014:11). In the ways that anthropologists work and study with other people, they become immersed in an environment of "joint activity" of experiencing the world and other possibilities of being and doing (Ingold 2008; Light 2015). Furthermore, anthropologists are in the unique position of translating various worldviews of project participants because they have the opportunity to collaborate across sectors, to act within multiple realities (McCabe and Briody 2016), bring material form to invisible cultural factors and forces (Stuedahl 2015), and ground what might otherwise feel abstract.

Halse and Boffi (2014) propose that design interventions can be a form of inquiry into new phenomena that has yet to be articulated both 
conceptually and physically. Design activities produce artifacts like sketches, models, service blueprints, and more that "carry traces" of ethnographic inquiry including empathy, open-endedness, and situatedness (Halse and Boffi 2014:4). By bringing "new ways of knowing" to the design process, design anthropology can challenge common understandings of how success and failure are shaped, how timeframes and time expenditure are viewed and how productivity is measured. Design anthropology can also challenge how imbalances of power and control are recognized, and how trust is established and sustained over time. New interpretations and experiences of time (i.e. "fast time" vs. "slow time") are needed to successfully link people, places, and products through layers of meaning (Manzini 2015:25) and to inform the tempo and cadence of creative production.

Returning to Detroit as an example, social movement organizing can illustrate how consideration of time and "new ways of knowing" could inform a social design process and align with existing mental models of social change. Stemming from Detroit's history of Civil Rights and Black Labor Union organizing and the Black Power Movement, many Black Detroiters today continue efforts towards social movement and community organizing. Amidst urban renewal, new members of the Black Power Movement formed New Era Detroit to work on neighborhood programs and mobilize to strengthen and support Black communities in Detroit (Warikoo 2015; New Era Detroit). The James and Grace Lee Boggs Center to Nurture Community Leadership continue to mobilize and implement new models towards transformational change and community sustainability. The Boggs Center, founded in 1995 in honor of the Civil Rights activists James and Grace Lee Boggs, has extensive alliances with community groups and food cooperatives across the city and an elementary school that was founded in 2013 (The Boggs Center, McFadden 2015). Since 1992 they have hosted the Detroit Summer youth program that draws volunteers from all over the country to repair homes, paint murals, organize music festivals, build community gardens, and participate in intergenerational and peer dialogues (The Boggs Center, McFadden 2015). Grace Lee Boggs, who passed away in 2015 at the age of 100 , has been internationally recognized for her book The Next American Revolution: Sustainable Activism for the Twenty-First Century, which she co-published with Scott Kurashige in 2012. In the face of inequality and poverty in Detroit, the authors advocate that "another world is possible" (Boggs and Kurashige 2012:20). In the book, Boggs and Kurashige stress a mission of transformational change in small but impactful ways. In the introduction Kurashige writes:

What we must see in Detroit is the prospect of living radically differently, when necessity and possibility combine to facilitate the beginning of a rupture with a culture of the industrial age. Since traditional forms of politics (including ostensibly 
oppositional forms) have failed so fantastically in Detroit, a qualitatively different kind of activism has taken root in the city, epitomized by organizations such as the youth leadership movement, Detroit Summer. Their work may appear small scale and the change they bring incremental: here a mural; there a community garden; a collection of poems for songs documenting the ideas of youth. But what they foster is an enduring spirit of humanism...." (Boggs and Kurashige 2012:17).

Kurashige's description of Detroit Summer aligns well with participatory design approaches. The example of Detroit Summer is framed as a prototype in an iterative process (small and incremental, a thing here, a thing there) that provides material evidence of an exploration in future-making (the beginning of the rupture and humanism). Furthermore, as an ongoing, iterative process, the work is not project-bound or budget-bound. As a summer program, the work belongs to a fluid, moving set of participants of all ages. The description communicates confidence in undefined, unprescribed, and exploratory ways of working and argues that it is necessary to do so. They write:

We must move toward a future lacking a clear-cut blueprint of what is to be done and shedding a dogmatic sense of the eternal truth but carrying with us a shared sense of the awarenesss, values, methods, and relationships necessary to navigate these uncharted waters. (Boggs and Kurashige 2012:21).

This excerpt typifies how Kurashige, Boggs, and the members of the Boggs Center are approaching future-making with an understanding that a map does not yet exist (uncharted waters, no blueprint). As a form of participatory design, they indicate that future-making will be an exploration in "new ways of knowing" through shared awareness and relationships. Both excerpts illustrate that the Boggs Center approach to future-making is unbounded and holistic. Detroit is seen as "a prospect" in living radically differently, as a way to materially, spatially, and interactively engage with "the future" through building things, spaces, and dialogues. The approach is also in some ways scale-less. What is seen as small and incremental materially is big and continuous socially.

The ideas presented in this text are reinforced by much of the writing on The Boggs Center website, in their newsletter, and in conversations I have had with their members. I see these approaches in stark contrast to the backdrop of the planning and community engagement efforts leading up to Detroit Future City Plan. The two examples show how differently participation can be understood in terms of approaches, expectations, and duration. Theoretically and materially, the future-making of The Boggs Center is more radically humanistic and participatory and illustrates how inclusion is framed in social movement organizing. This next section builds on this idea by suggesting that a 
longer-term, slower, and less structured approach may help shift (or set) expectations of social design process.

\section{Social Design Process and "Embedded-ness"}

In the well-known book Rules for Radicals (1971), Saul Alinsky discusses the importance of a deep social commitment when it comes to social movement and community organizing. His strategies have implications for the practice of the social design process because his approach is inherently rooted in first establishing trust in order to move forward with a project or program. He writes, "I know that in a community, working as an organizer, I have unlimited patience in listening to and talking to the local residents. Any organizer must have this patience" (Alinsky 1971:68). He adds that, "in the beginning, the organizer must establish his identity or, putting it another way, get his license to operate" (Alinsky 1971:98). He must be able to "meet the question, 'Who asked you to come in here?' with the answer, 'You did.'” (Alinsky 1971:101) Alinsky's strategy suggests that time is necessary to be accepted as part of the fabric of a community - that comradeship is necessary for socially transformative work to take shape.

Similar advice has been expressed with regard to participatory design. As Reason (2004) writes, "participation is a delicate matter. It is clearly not possible to simply enter a community and announce that we are all going to participate" (Reason 2004:271). Barab et al. (2004:255) write about how they "learned to listen first and then talk, placing emphasis on establishing trust, respect, and shared intention rather than simply imposing an instructional design...design became an outgrowth of healthy relationships, as opposed to our relationships being an outgrowth of good design." Alinsky's advice to organizing and Reason and Barab et al.'s approach to participatory design is indicative of a slower, more embedded approach to address the roots of social injustices that are imposed through spatial and governmental controls (Low 2011) and in the urban design and planning process. Akama, Pink, and Fergusson (2015) suggest that "entanglement," or a dissolving of boundaries, between design and anthropology underpins the commitment to creating a shared theoretical and conceptual foundation. This type of commitment requires a longitudinal look and a long-term approach. Blomberg and Karasti's (2015) description of "co-realization" also engages with a longer-term investigation and study of systems in use. Co-realization takes a "being there" approach that encourages spontaneous interactions, a shared practice and ongoing dialogue between users and designers. Blomberg and Karasti explain:

It [co-realizaton] starts from the observation that the full implications of a new system for work practices cannot be grasped by studying the work as it is now, but will only be 
revealed in and through the systems subsequent use. (2015:398).

While participatory design as an activity may not continue on past early prototyping, co-realization is described as a way to develop an ongoing relation to changes brought about by a new design.

My own ongoing partnerships in my neighborhood of JeffersonChalmers in Detroit is helpful in illustrating how the value of design anthropology as "slow-ness" and "embedded-ness" can bring continuity, consistency, and commitment to the social design process. Most of my work has been in support of four neighborhood-based organizations. Financially supported by my university position and a private practice, I have the benefit of offering an open-ended commitment and pro-bono design services. I have assisted in the organizing and hosting of numerous community building activities, events and fundraisers where, among other creative tasks, I facilitate arts and/or crafts projects for children and teenagers. I have also led the planning for a children's art show, at the request of one of my partners, and a photography exhibit to raise awareness about parks usage. I have supported three of these organizations on visions for indoor and outdoor public spaces for the neighborhood and have provided architectural renderings, landscape plans, graphic design, promotional materials, website design, after-school programming support, business plan writing, and grant writing support.

As a resident, I have experienced the community engagement demands of outside organizations and planning efforts looking for input from residents. While these events bring attention to issues and resources to the neighborhood, I have recognized a disconnectedness in the agendas of community charrettes hosted by design and planning professionals, where participants are documented and surveyed, our opinions, preferences, desires extracted, and we are encouraged to attend multiple meetings in order to remain in the process. I have also seen students arrive for a week or two, with their own grant money to interview, observe, and learn from community leaders who are not financially compensated for their time. Projects are sometimes left unfinished. The backdrop of these events is a neighborhood that is experiencing significant change. In 2016, the neighborhood received a historic designation (Benedetti 2016) and in April of 2017 a RFP (request for proposal) for a Neighborhood Development and Implementation Plan (City of Detroit, Office of Contracting and Procurement). One of the projects I have been supporting for two and a half years will be directly affected by this implementation plan. Recently, at a fundraiser, a woman said to me, "I love your neighborhood, but I am waiting for it to gentrify." I did not probe, but my assumption was that, in her declaration of waiting for gentrification, her "love" for the neighborhood referred to the architectural distinctness found in the neighborhood, riverfront access and possibly the historic designation. She was not referring to the current Black senior citizen majority, many living on fixed or low incomes that 
make up the distinctly human value of the neighborhood.

In support of "embedded-ness," all of these experiences (and challenges) have radically reshaped my ways of knowing, my approaches to creative collaboration, and my commitment to community partnerships. I see this as working design anthropologically, not in the formal sense of fieldwork ethnography, but with a great sensitivity to how sense-of-place-ness informs my work, my capacity as a creative person, and the types of roles that I can best play in the realizations of their visions.

\section{Conclusion}

While the language of "participation", "empathy", and "inclusiveness" shapes social design process today, more deeply anthropological approaches can help deliver more substantially on these promises. Bannon and Ehn (2012) assert that as design moves from spaces of consumer products to developing services, systems, and environments that support sustainability, design is more broadly recognized as a process for radical change. In places like Detroit that are negotiating conditions of gentrification, radical change needs to be defined and created by the communities themselves. Familiar frameworks of design thinking and human-centered design may not be enough. Designers may find it necessary to engage with more radical approaches that assertively challenge the identity of design, the designer, and notions of "success" in the design process. Design has the opportunity to move further beyond collaboration and empathy to collectivism, and what Hillgren et al. (2016) refer to as 'agonism' and 'commoning' as ways to embrace plurality, mobilize marginal actors, bring together different voices, and push for equal and mutual ownership.

I have attempted to illustrate here that in contexts of urban renewal, design anthropology as social design process can provide an alternative to current design approaches and practices. It can do this by resisting the spatiotemporal factors that reinforce conditions of inequality in design and the design process. Social design may move from social impact to social transformation. It may also lead to a re-valuing of the immaterial human bonds that are critical to radical social change. For design to make this shift will require that design education and design degree programs begin to adapt curricula away from the traditional visual arts foundation and become more interdisciplinary and collaborative and engage more intimately with social work, social sciences, and the humanities. Design education may involve a more flexible and fluid expectation of design production where an end product of design may not exist, but where new, more social approaches can inform new futures for the profession. 


\section{References}

Ager, Susan. 2017. "Tough, Cheap, and Real, Detroit is Cool Again."

National Geographic. https://www.nationalgeographic.com/taking-backdetroit/see-detroit.html. Accessed December 2, 2017.

Alinsky, Saul. 1971. Rules For Radicals. New York, NY: Random House.

Akama, Yoko, Dagny Stuedahl, and Izak Van Zyl. 2015. “Design

Disruptions for Contested, Contingent and Contradictory Future-making."

Interaction Design and Architecture Journal N.26: 132-148

Akama, Yoko, Sarah Pink, and Annie Fergusson. 2015. "Design+ ethnography+ futures: Surrendering in uncertainty." Proceedings of the 33rd Annual ACM Conference Extended Abstracts on Human Factors in Computing Systems: 531-542.

Anusas, Mike, and Rachel Harkness. 2014. "Things Could Be Different: Design Anthropology as Hopeful, Critical and Ecological." Paper for the seminar "Ethnographies of the Possible." April 10. Aarhus, DK. The Research Network for Design Anthropology.

Applebome, Peter. 2016. "In Detroit's 2-Speed Recovery, Downtown Roars and Neighborhoods Sputter." August 12 https://www.nytimes.com/2016/08/13/us/detroit-recovery.html. Accessed December 2, 2017.

Bannon, Liam J. and Pelle Ehn. 2012. "Design Matters in Participatory Design." Routledge Handbook of Participatory Design: 37-63.

Barab, Sasha A., Michael K. Thomas, Tyler Dodge, Kurt Squire, and Markeda Newell. 2004 “Critical Design Ethnography: Designing for Change. Anthropology \& Education Quarterly 35, no. 2: 254-268. https://doi.org/10.1525/aeq.2004.35.2.254

Benedetti, Marti. 2016. “Jefferson-Chalmers Neighborhood Gets National Treasure Status, First Site in Michigan to Earn Designation." Crain's Detroit Business. September 07, updated September 13. Accessed Nov 11, 2017.

City of Detroit, Office of Contracting and Procurement on Behalf of the Planning and Development Department, Maurice Cox, Director and Mayor Mike Duggan Jefferson / Chalmers RFP \#17MC949, Neighborhood Development and Implementation Plan, Project Information- April 2017. Online. Accessed November 11, 2017.

Berglund, Lisa Katarina. 2017. "Experts of Crisis: Exclusive Planning Discourse and Community Resistance in Detroit." Dissertation for University of California, Los Angeles, ProQuest Dissertations Publishing.

Berman, Marshall. 1982. All That is Solid Melts into Air; The Experience of Modernity. London, England: Penguin Books.

Bichard, Jo-Ann and Rama Gheerawo. 2011. The Ethnography in Design. 
In Design Anthropology, 45-55. Alison J. Clarke, ed. Vienna. Springer.

Bjögvinsson, Erling, Pelle Ehn, and Per-Anders Hillgren. 2010.

"Participatory Design and Democratizing Innovation." In Proceedings of the 11th Biennial Participatory Design Conference, 41-50.

https://doi.org/10.1145/1900441.1900448

Bjögvinsson, Erling, Pelle Ehn, and Per-Anders Hillgren. 2012. “Design

Things and Design Thinking: Contemporary Participatory Design

Challenges." Design Issues 28, no. 3: 101-116.

https://doi.org/10.1162/DESI a 00165

Blomberg, Jeanette, and Helena Karasti. 2013. "Reflections on 25 years of Ethnography in CSCW." Computer Supported Cooperative Work (CSCW) 22, no. 4-6: 373-423. https://doi.org/10.1007/s10606-012-9183-1

Blouin, Lou. 2017. "An Hour With... Dan Pitera, Executive Director, Detroit Collaborative Design Center." hourdetroit.com. August 9. Accessed: Nov 10, 2017.

Bockmeyer, Janice L. 2000. "A Culture of Distrust: The Impact of Local Political Culture on Participation in the Detroit EZ." Urban Studies 37, no. 13: 2417-2440. https://doi.org/10.1080/00420980020080621

Boggs, Grace Lee, and Scott Kurashige. 2012. The Next American Revolution: Sustainable Activism for the Twenty-first Century. University of California Press. Berkeley and Los Angeles.

Bowen, Simon. 2010. "Critical theory and participatory design." In Proceedings of $\mathrm{CHI}$.

Buchanan, Richard. 1992. "Wicked Problems in Design Thinking." Design Issues 8, no. 2 (1992): 5-21. https://doi.org/10.2307/1511637

Bush, Anne. 2003. "Beyond Pro Bono; Graphic Design's Social Work.” In Citizen Designer: Perspectives on Design Responsibility. Steven Heller and Veronique Vienne, eds., 25-31. New York, NY: Allworth Press.

Cefkin, Melissa. 2012. "Close Encounters: Anthropologists in the Corporate Arena." Journal of Business Anthropology 1 (1): 91-117. https://doi.org/10.22439/iba.v1i1.3548

Clarke, Alison J. 2011. "The Anthropological Object in Design: From Victor Papanek to Superstudio. In Design Anthropology, 74-87. Alison J. Clarke, ed. Vienna: Springer.

Clement, Daniel, and Miguel Kanai. 2015. "The Detroit Future City: How Pervasive Neoliberal Urbanism Exacerbates Racialized Spatial Injustice." American Behavioral Scientist 59, no. 3: 369-385. https://doi.org/10.1177/0002764214550306

Cresswell, Tim. 2006. On the Move: Mobility in the Modern Western World. New York and London: Rutledge. 
Cross, Nigel. 2011. Design Thinking: Understanding How Designers Think and Work. Bloomsbury. London and New York. https://doi.org/10.5040/9781474293884

Dandelion. Website: dndln.org Accessed January 31, 2018.

Detroit Long Term Planning Committee. 2012. Detroit Future City, 2012. Detroit Strategic Framework Plan. Sources from cd and on the website detroitlongterm.com.

Detroit Collaborative Design Center. Website: http://www.dcdcudm.org/about/staff/dan.html. Accessed January 31, 2018.

Downtown Detroit Partnership. Website.

http://downtowndetroit.org/experience-downtown/capital-park/. Accessed January 30, 2018.

Florida, Richard L. 2002. The Rise of the Creative Class: and How it's Transforming Work, Leisure, Community and Everyday Life. Philadelphia: Basic Books.

Florida, Richard L. 2013. "More Losers Than Winners in America's New Economic Geography." The Atlantic. citylab.com January 30. Accessed: May 16, 2017.

Foley, Aaron. 2013. "The White Entreprenurial Guy Detroit Meme is the Funniest Detroit Meme." jalopnik.com. April 12. Accessed: May 16, 2017.

Fournier, Ron. 2015. "Purpose-driven Millennials Who Don't Remember 'Old Detroit' Build Anew." Crain's Detroit Business.

http://www.crainsdetroit.com/article/20151114/NEWS/311159986/pu rpose-driven-millennials-who-dont-remember-old-detroit-buildanew?CSAuthResp=1\%3A\%3A371281\%3A1040\%3A24\%3Asuccess $\% 3 \mathrm{~A}$ 225696445B3E1DEE121EEB55C7CC6586. Accessed: December 2, 2017.

Fry, Tony. 1989. "A Geography of Power: Design History and Marginality." Design Issues 6(1):15-30. https://doi.org/10.2307/1511575

Fry, Tony. 2008. Design Futuring: Sustainability, Ethics, and New Practice. Berg. Oxford and New York.

Fuller, Richard Buckminster. 1973. Utopia or Oblivion. Woodstock, NY: The Overlook Press.

Gatt, Caroline, and Tim Ingold. 2013. "From Description to Correspondence: Anthropology in Real Time." In Design Anthropology: Theory and Practice, 180-196. eds. Wendy Gunn, Ton Otto, Rachel Charlotte Smith. Bloomsbury, London and New York.

Gerber, Alix. 2015. "Exploring Anthropological Imagination. Conf. Design Anthropological Futures for Design Anthropology." vol. 3.

Graffam, G. 2010. “Design Anthropology Meets Marketing.” Anthropologica, 155-164. 
Gregory, Siobhan. 2012. "Detroit is a Blank Slate: Metaphors in the Journalistic Discourse of Art and Entrepreneurship in the City of Detroit." In Ethnographic Praxis in Industry Conference Proceedings, 217-233. Blackwell Publishing Ltd.

Gregory, Siobhan. 2015. "What's on the Surface: Aesthetic Divides in Signage, Muraling, and Other Forms of Surface Treatment in a "Renewing" Detroit Landscape." Progressive Planning Magazine. Fall.

Halse, Joachim, and Laura Boffi. 2014. "Design Interventions as a Form of Inquiry. Paper for the seminar Ethnographies of the Possible." April 10th. Aarhus, DK, The Research Network for Design Anthropology.

Harvey, David. 2012. Rebel cities: From the right to the city to the urban revolution. London: Verso Books.

Hasso Plattner Institute of Design at Stanford. Bootcamp Bootleg. http://longevity3.stanford.edu/designchallenge2015/files/2013/09/Boo tleg.pdf Accessed: January 31, 2018.

Hillgren, Per-Anders, Anna Seravalli, and Anders Emilson. 2011. "Prototyping and Infrastructuring in Design for Social Innovation." In CoDesign 7(3-4): 169-183. https://doi.org/10.1080/15710882.2011.630474

Hillgren, Per-Anders, Anna Seravalli, and Mette Agger Eriksen. 2016. "Counter-hegemonic Practices; Dynamic Interplay Between Agonism, Commoning and Strategic Design." Strategic Design Research 9(2): 89.

Hunt, J. 2011. "Prototyping the Social: Temporality and Speculative Futures at the Intersection of Design and Culture." In A. J. Clarke (Ed.), Design Anthropology. Object Culture in the 21st Century, 33-44. Wien \& New York: Springer.

IDEO. 2011. Human Centered Design Toolkit. Printed in Canada.

Ingold, Tim. 2008. "Ethnography is not Anthropology." In Proceedings of the British Academy. Vol. 154, pp. 69-92.

Jacobs, Jane. 1961. The Death and Life of Great American Cities. New York: Random House.

Kjærsgaard, M., and Laurens Boer. 2015. "The Speculative and the Mundane in Practices of Future-Making-Exploring Relations Between Design Anthropology and Critical Design." In Research Network for Design Anthropology, seminar.

Lefebvre, Henri. 1996. Writings on Cities. Translated by Eleonore Kofman and Elizabeth Lebas. Oxford: Blackwell.

Lewan, Amanda. 2014. "Dan Pitera." Detroit Urban Innovation Exchange website. http://www.uixdetroit.com/people/danpitera.aspx. January 17. Accessed: Nov 10, 2017. 
Light, Ann. 2015. “Troubling Futures: Can Participatory Design Research Provide a Generative Anthropology for the 21st Century?" In Interaction Design and Architecture (s) 26: 81-94.

Lorimor, Jason. 2013. "Opinion: Detroit is the Opportunity of a Generation.” modeldmedia.com. April 09. Accessed May 16, 2017.

Low, Setha M. 1997. "Urban fear: building the fortress city." City \& Society 9(1):53-71.

https://doi.org/10.1525/ciso.1997.9.1.53

Low, Setha M. 2009. "Maintaining Whiteness: The Fear of Others and Niceness." Transforming Anthropology, 17(2):79-92. https://doi.org/10.1111/i.1548-7466.2009.01047.x

Low, Setha M. 2011. "Claiming Space for an Engaged Anthropology: Spatial Inequality and Social Exclusion." American anthropologist 113(3):389-407. https://doi.org/10.1111/i.1548-1433.2011.01349.x

Maldonado, Tomas and John Cullars. 1991. "The Idea of Comfort." Design Issues 8(1):35-43.

https://doi.org/10.2307/1511452

Manzini, Ezio, translated by Rachel Coad. 2015. Design, When Everybody Designs: An Introduction to Design for Social Innovation. Boston: MIT press.

Margolin, Victor. 1998. "Design for a Sustainable World." Design Issues 14(2):83-92.

https://doi.org/10.2307/1511853

McCabe, Maryann, and Elizabeth K. Briody. 2016. "Working in Liminal States: Fluidity and Transformation in Organizations." Journal of Business Anthropology 1(1): 1-12.

https://doi.org/10.22439/iba.v1i1.4957

McFadden, Robert. 2015. Grace Lee Boggs, "Human Rights Advocate for 7 Decades, Dies at 100." New York Times. October 5.

https://www.nytimes.com/2015/10/06/us/grace-lee-boggs-detroitactivist-dies-at-100.html. Accessed Nov 11, 2017.

McGraw, B. 2013. "Meet the Downtown Residents Who Say They Are Being Pushed Aside for The 'New Detroit.'" Deadline Detroit Business. May 12. Online. http://www.deadlinedetroit.com. Accessed November 16, 2017. 
Miller, Christine. 2014. "Lost in Translation?" Ethics and Ethnography in Design Research. JBA Special Issue 1: 62-78.

https://doi.org/10.22439/iba.v1i1.4262

Montgomery, Alesia F. 2015. "Different futures for different neighborhoods: The sustainability fix in Detroit." Ethnography 16(4): 523-555. https://doi.org/10.1177/1466138115570460

Mulgan, Geoff. 2014. "Design in Public and Social Innovation: What Works and What Could Work Better." Nesta. https://www.nesta.org.uk/publications/design-public-and-socialinnovation Accessed November 8, 2017.

Mulgan, Geoff, Simon Tucker, Rushanara Ali, and Ben Sanders. 2007. "Social Innovation: What it is, Why it Matters and How it Can Be Accelerated." Working Paper. Skoll Centre for Social Entrepreneurship, Oxford Said Business School website. https://www.sbs.ox.ac.uk/facultyresearch/skoll/research/social-innovation-reports-resources/socialinnovation-what-it-why-it-matters-and-how-it-can-be-accelerated. Accessed Nov 8, 2017.

Murray, Robin, Julie Caulier-Grice, and Geoff Mulgan. 2010. The Open Book of Social Innovation. London: National endowment for science, technology and the art.

New Era Detroit. http://neweradetroit.com/about/missionstatement/. Accessed Nov 12, 2017.

Norton, Lisa. 2012. "Integral Design Thinking, Guessing the Future." Article from Integral Leadership Review. March.

Nussbaum, Bruce. 2010. "Is Humanitarian Design the New Imperialism?" Fast Company Design, Vol. 2013: Fast Company.

Otto, T., \& Smith, R. C. 2013. "Design Anthropology: A distinct Style of Knowing." Design Anthropology: Theory and Practice, 1-29. Gunn, W., Otto, T., \& Smith, R. C. (Eds.) A\&C Black.

Papanek, Victor. 1984. Design for the Real World: Human Ecology and Social Change. New York and London: Thames and Hudson.

Papanek, Victor. 1988. "The Future Isn't What It Used to Be." Design Issues 5(1):4-17.

https://doi.org/10.2307/1511555 
Pink, Sarah. 2014. "Digital-Visual-Sensory-Design Anthropology: Ethnography, Imagination and Intervention." Arts and Humanities in Higher education, 13(4), 412-427. https://doi.org/10.1177/1474022214542353

Reason, Peter. 2004. "Critical Design Ethnography as Action Research." Anthropology \& Education Quarterly 35(2):269-276. https://doi.org/10.1525/aeq.2004.35.2.269

Robertson, Toni, and Jesper Simonsen. 2012. "Challenges and Opportunities in Contemporary Participatory design." Design Issues 28(3): 3-9. https://doi.org/10.1162/DESI a 00157

Ross, Kristin. 1988. The Emergence of Social Space: Rimbaud and the Paris Commune (Vol. 60). Minnesota: University of Minnesota Press. https://doi.org/10.1007/978-1-349-19800-9

Rutheiser, Charles. 1997. "Beyond the Radiant Garden City Beautiful: Notes on the New Urbanism." City \& Society 9(1):117-133. https://doi.org/10.1525/city.1997.9.1.117

Sacchetti, Vera. 2011. Design Crusades: A Critical Reflection on Social Design. School of Visual Arts. New York, NY. Unpublished.

Schein, Richard H. 1999. "Teaching 'Race' and the Cultural Landscape." Journal of Geography 98(4):188-190. https://doi.org/10.1080/00221349908978881

Scipioni, J. 2015. "Meet the Millennials Who Say Detroit Is the Place to Be." http://www.foxbusiness.com/features/2015/09/16/meetmillennials-who-say-detroit-is-place-to-be.html. Accessed December 2, 2017.

Stuedahl, Dagny. 2015. "Future Orientation in Design, Participation and Learning." IxD\&A 26: 149-161.

Swyngedouw, Erik, Frank Moulaert and Arantxa Rodriguez. 2002. "Neoliberal Urbanization in Europe: Large-Scale Urban Development Projects and the New Urban Policy." Antipode 34(3):542-577. https://doi.org/10.1111/1467-8330.00254

The Albert Capitol Park. Website. http://www.thealbertcapitolpark.com/. Accessed: November 16. 2017. 
The Boggs Center. Website: www.boggscenter.org. Accessed: November 11, 2017.

Tunstall, Elizabeth. 2013. "Decolonizing Design Innovation: Design Anthropology, Critical anthropology, and Indigenous Knowledge." Design Anthropology: Theory and Practice: 232-250.

Warikoo, Niraj. 2015. "A Next Generation of Black Activism Gains Steam." Detroit Free Press online. Dec. 7. Accessed Nov 11, 2017.

Wasson, Christina. 2000. "Ethnography in the Field of Design." Human Organization 59(4): 377-388.

https://doi.org/10.17730/humo.59.4.h13326628n127516

Wilkins, Craig L. 2007. The Aesthetics of Equity: Notes on Race, Space, Architecture, and Music. Minnesota: University of Minnesota Press.

Woods, Ashley. 2013. "White Entrepreneurial Guy Detroit Meme, Or, A Viral Tale Of Two Cities." Online. huffingtonpost.com. April 12. Accessed May 16, 2017.

Siobhan Gregory is an industrial designer and design anthropologist living and working in Detroit. Her research focuses on a more anthropologically based process of human-centered design practice. In the business sector, she draws on anthropological theory and methods to help organizations form deep and meaningful connections with their customers through culturally informed product development, service innovations, and brand direction. Siobhan works with neighborhoodbased community groups in the Jefferson-Chalmers neighborhood on Detroit's east side to help realize community spaces. She teaches industrial design and ethnographic research methods for designers at Wayne State University. 